
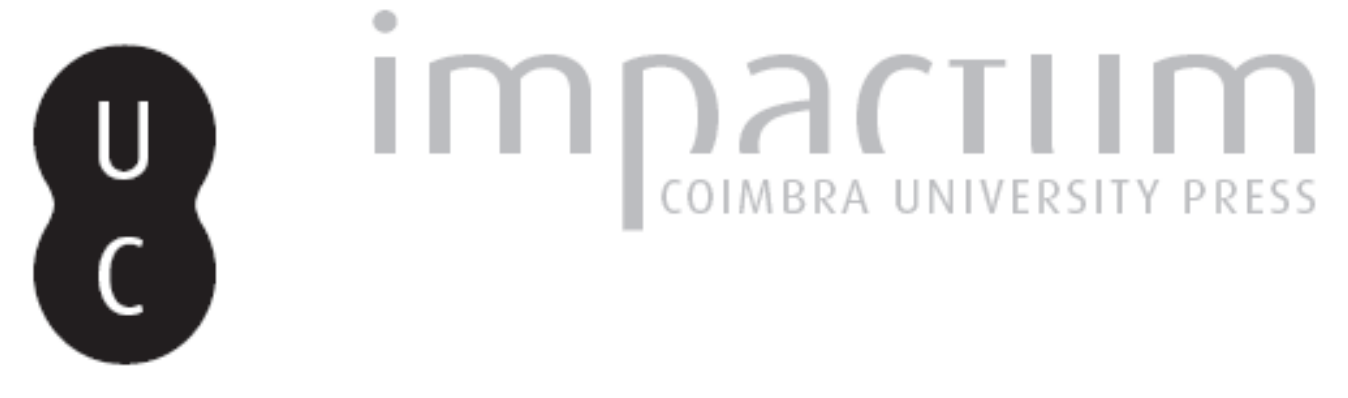

\title{
On the divorce between philosophy and argumentation theory
}

Autor(es): $\quad$ Ribeiro, Henrique Jales

Publicado por: $\begin{aligned} & \text { Faculdade de Letras da Universidade de Coimbra, Instituto de Estudos } \\ & \text { Filosóficos }\end{aligned}$

URL persistente:

URI:http://hdl.handle.net/10316.2/29420

DOI:

DOl:http://dx.doi.org/10.14195/0872-0851_42_5

Accessed : $\quad$ 26-Apr-2023 13:42:36

A navegação consulta e descarregamento dos títulos inseridos nas Bibliotecas Digitais UC Digitalis, UC Pombalina e UC Impactum, pressupõem a aceitação plena e sem reservas dos Termos e Condições de Uso destas Bibliotecas Digitais, disponíveis em https://digitalis.uc.pt/pt-pt/termos.

Conforme exposto nos referidos Termos e Condições de Uso, o descarregamento de títulos de acesso restrito requer uma licença válida de autorização devendo o utilizador aceder ao(s) documento(s) a partir de um endereço de IP da instituição detentora da supramencionada licença.

Ao utilizador é apenas permitido o descarregamento para uso pessoal, pelo que o emprego do(s) título(s) descarregado(s) para outro fim, designadamente comercial, carece de autorização do respetivo autor ou editor da obra.

Na medida em que todas as obras da UC Digitalis se encontram protegidas pelo Código do Direito de Autor e Direitos Conexos e demais legislação aplicável, toda a cópia, parcial ou total, deste documento, nos casos em que é legalmente admitida, deverá conter ou fazer-se acompanhar por este aviso.

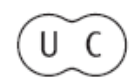




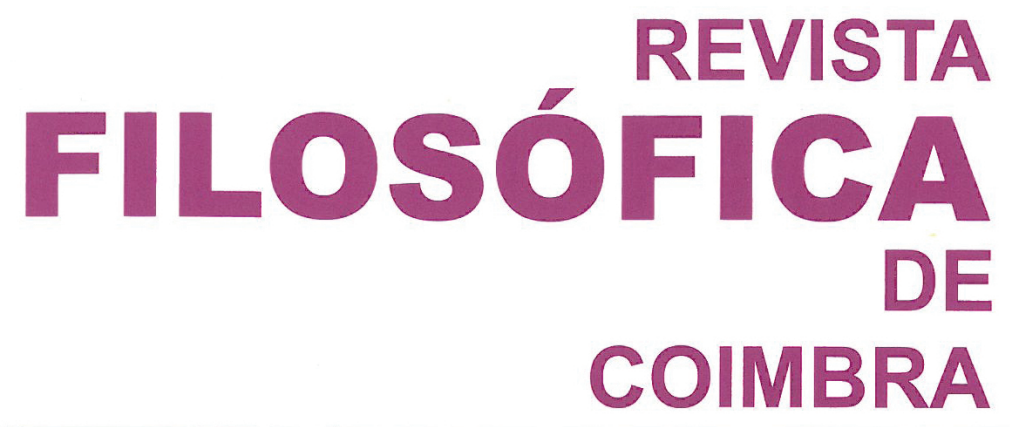

vol. 21 - número 42 - outubro 2012

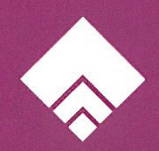




\title{
ON THE DIVORCE BETWEEN PHILOSOPHY AND ARGUMENTATION THEORY*
}

\author{
HENRIQUE JALES RIBEIRO**
}

\begin{abstract}
The author compares the views of analytic philosophy regarding argumentation and its philosophical relevance, with those of contemporary argumentation theories, in general, regarding the philosophical idea of meaning. He shows that, in the first case, the theory of meaning (Russell, Wittgenstein, Quine, and others) excludes argumentation and an approach on it, and, in the second, argumentation theories exclude, in practice, a theory of meaning, at least insofar the concept of meaning must be philosophically understood. The author concludes studying the role of each of these theories (meaning/argumentation) in Stephen Toulmin's philosophy, where, by contrast and according to his interpretation, rhetoric and argumentation are at the core of the foundations of philosophy and of human knowledge and action as a whole.
\end{abstract}

Keywords: analytic philosophy, argumentation theory, formal logic, informal logic, Quine, rhetoric, theory of meaning, Toulmin, Wittgenstein.

Resumo: O autor compara as perspectivas da filosofia analítica a respeito da argumentação e da sua importância filosófica, com as das teorias da argumentação contemporâneas, de maneira geral, a respeito da ideia filosófica de significação.

* This article is an extended version of a paper presented at the International Colloquium "Inside Arguments: Logic vs. Argumentation Theory" (Faculty of Letters of the University of Coimbra, Portugal, 24-26 March 2011). For a further development of the author's views until now, see Ribeiro (2012a), (2012b) and (2012c).

** Associate Professor at the Faculty of Letters of the University of Coimbra (Department of Philosophy, Communication and Information). Coordinator of the Research Group "Teaching Logic \& Argumentation”, of the the Research Unit "Language, Interpretation \& Philosophy" (Portuguese Foundation for Science and Technology). Contact: jalesribeiro@gmail.com 
Ele mostra que, no primeiro caso, a teoria da significação (Russell, Wittgenstein, Quine, e outros) exclui a argumentação e uma abordagem sobre ela, e, no segundo, as teorias da argumentação excluem, na prática, uma teoria da significação, pelo menos, na medida em que o conceito de significação deve ser filosoficamente compreendido. $\mathrm{O}$ autor conclui estudando o papel de cada uma dessas teorias (significação/argumentação) na filosofia de Stephen Toulmin, onde, por contraste e de acordo com a sua interpretação, a retórica e a argumentação estão no cerne das fundações da filosofia e do conhecimento e acção humanas no seu conjunto.

Palavras chave: filosofia analítica, lógica formal, lógica informal, Quine, retórica, teoria da argumentação, teoria da significação, Toulmin, Wittgenstein.

\section{Introduction: On the divorce between theory of meaning and theory of argumentation}

One of the most surprising conclusions that researchers on contemporary argumentation theory and on analytic philosophy may draw, after attempting to read the latter in the light of the former, is that we do not find the mere concept of argument, neither among the founders of the analytic movement, nor among most of their scholars to this day. For example, what do Russell, Wittgenstein or Quine have to say about the idea that argumentation is a characteristic expression of the exercise of human reason, that we argue in different ways, which may be studied by themselves, i.e. they may be the subject of specialised research (either philosophical or not)? More precisely, what do these philosophers have to say about the idea that argumentation is a vehicle of meaning in ordinary language? Apparently, nothing. Indeed, as mentioned, the concept of argumentation, in the senses I mentioned, appears nowhere in their books or other publications. ${ }^{1}$ However, a large number of analytic philosophers who teach formal logic at Universities in Europe and the United States of America (some of whom are attending this international colloquium) insist on underlining that the very same logic, when applied to ordinary language, is both an essential tool for achieving clarity and precision in our reasoning, and provides the fundamental framework for the study of argumentation as it takes place in daily life. In the past decades, after informal logic emerged and developed, and in particular, after what became commonly known as "critical thinking", it became

1 The terms "argument" and "argumentation" are completely absent from the Index of A Companion to Analytic Philosophy (Martinich \& Sosa 2001). 
common to relate formal logic with the idea of it, in the sense that it would also be a privileged means of developing the skills that characterise it (see Ribeiro 2005). However, the extension of formal logic to argumentation lacks theoretical and metatheoretical grounds in the philosophical scope per se, as I started by suggesting. Analytic philosophers, in general, find that the key or nuclear concept, which is at the core of the relevant concepts in terms of philosophy of language, is meaning, and meaning is not connected, neither directly nor indirectly, to argumentation. ${ }^{2}$

Paradoxically, or perhaps not, some analytic philosophers have seen in argumentative rationality and in its enormous social, cultural and political advantages one of the most distinctive marks of analytic philosophy, compared to other philosophical movements, as is the case of the "continental" movements. So, in his well-known book The Dialogue of Reason, J. Cohen wrote:

By its systematic exploration of reasons and reasoning, analytic philosophy helps to consolidate the intellectual infrastructure that is needed for systems of social organization within which disputes are reflected in argument and counter-argument, rather than in the use of violence. By virtue of its preoccupation with rationality it promotes awareness that the intellectual merit of a person's opinion does not hinge on his membership of a particular party, priesthood, or hermetic tradition. (Cohen 1986: 61-62)

And, more recently, F $\phi$ llesdal managed to write that the emphasis of analytic philosophy on

argument and justification (...) will make life more difficult for political leaders and fanatics who spread messages which do not stand up to critical scrutiny, but which nevertheless often have the capacity to seduce the masses into intolerance and violence. Rational argument and rational dialogue are of the utmost importance for a well-functioning democracy. To educate people in theses activities is perhaps de most important task of analytic philosophy. (Follesdal 1997: 15-16)

No need to add that, as pertinent as this association between analytic philosophy and the idea of argumentation or of argumentative rationality may be, it is not a question of studying argumentation or argumentative rationality on their own. (In this regard, Cohen was certainly an exception

2 See my remarks on this subject in Ribeiro (2012b: $1 \mathrm{ff}$.). 
among analytic philosophers. $)^{3}$ And the reason, as I began by saying, is that analytic philosophy introduced itself basically as a theory of meaning, which is not linked, neither directly nor indirectly, to argumentation or to any other theory thereof. ${ }^{4}$ I suggest there is a clear divorce between (analytic) philosophy and argumentation theory.

In another context-of contemporary argumentation theories-there seems to be a similar divorce, for the inverse reasons, as that found in analytic philosophy. Speaking of "argumentation theories", I mean those theories where we can find explicitly not only an approach to argumentation in general but also, too, an argument theory, that is, a theory about the way we can assess and explain the products of argumentation: arguments. More precisely, I mean the theories which are conceived, from the beginning, as interdisciplinaries ones, according to meta-systematic connections as those sustained in books like Fundamentals of Argumentation Theory (Eemeren et al. 1996: 1-26). In my view, as I showed elsewhere, this interdisciplinary concept of argumentation theory is one of the most important intellectual revolutions in the history of mankind since the ancient Greece; an ongoing revolution, whose course and development we can always influence in the right direction (see Ribeiro 2012b: 1-12).

From the perspective of this framework, I would say that while for analytic philosophy there is meaning without argumentation, for contemporary argumentation theory there is argumentation without meaning. Meaning is the set of philosophical and even, to some extent, metaphysical presuppositions, which are generally the grounds of our arguments: That the existence of meaning in our arguments and even in the exchange of such arguments, in society, entails researching the status of what we call "reason", particularly when compared to other forms of discourse which are not, at least apparently, "rational" (but that, like the latter, regard knowledge and human action); that, for there to be meaning, the world must have some essential properties or be structured in this or that manner and not in an other one; or that, finally, the existence of meaning, particularly when it is mediated by argumentation in society,

3 The exception, in my view, proves the rule. In fact, in the case of Cohen and his relationship with analytic philosophy, one could say that the exceptional nature of his views on argumentation and its relevance for (the development of) analytic philosophy in the 80's, justify completely my interpretation. See Cohen (1977) and (1989).

${ }^{4}$ One could even say, in a certain sense, that some analytic schools (as the logical positivism) have ignored the metaphysical foundations of meaning. See Katz (1990). For the role of the meaning theory in analytic philosophy and its (disastrous) consequences until Carnap and others, see the remarquable Introduction to Coffa (1991). 
allows us to draw more or less fundamental conclusions of ethical and even political nature, about inter-personal relations and relations between cultures and civilisations; it is presuppositions like these that are practically absent from most contemporary argumentation theories. (Curiously, they are manifest in some philosophical argumentation theories, like Habermas' theory, besides those coming from rhetoric properly called. The biggest constraint, however, is that in contrast with the theories to which I have alluded above [informal logic, pragma-dialectics, etc.], they do not offer any methodology of assessing and interpreting arguments. They are not, in general, argument theories.) It is this more general divorce between philosophy and argumentation theory that makes "experts" in the latter largely underestimate philosophy's potential input to the study of argumentation. The widespread idea is that argumentation is an essentially technical subject-matter, that can be studied and characterised on its own, regardless of all philosophically and/or metaphysically-based assumptions. Therefore, argumentation theorist appears as an expert in a interdisciplinary research field which, constitutionally, has nothing to do with philosophy. In other words, the input of philosophy to argumentation study will always be external and, ultimately, dispensable and unessential.

Of course, by saying that for contemporary argumentation theories there is argumentation without meaning, I am obviously not asserting that, for these experts, there is absolutely no meaning in (and through) argumentation; or that the concept of meaning does not make any sense to them. That is not, at all, what I mean. Arguments have always more or less meaning, to the extent that they are more or less correct, in formal and material terms. Yet, once again, this is a matter that the expert approaches fundamentally in technical terms, within the framework of this or that theory without philosophical presuppositions. These are the type of questions he will ask: Are these or those presuppositions, or these or those conclusions, acceptable as the assumptions/conclusions of this or that argument? What kind of schemes underlie this or that argument and how may it be counter-argued? To some extent, it is a meaning to be understood pursuant to the limitations of a technically prepared and enlightened intelligence, just as, by analogy, it is supposed to be the best interpretation that each one of us must make of the implementation of laws in our daily lives. It is not exactly the philosophical and metaphysical meaning I have in mind.

This perception of argumentation as something that does not have philosophical presuppositions became common in the last quarter of the 20th century, when argumentation theory was first seen as a neutral, interdisciplinary domain, that would receive different inputs from specialised domains, such as linguistics, sociology or communication 
theory, the starting point being a "unifying perspective of reasoned discourse, which is to provide a general framework for studying the interplay of pragmatic factors". This is the concept found in the well-known book, already quoted above Fundamentals of Argumentation Theory (see Eemeren et al. 1996: 12). In October 2008, at an international congress celebrating the fiftieth anniversary of Perelman's and Toulmin's books (respectively, La nouvelle rhétorique: Traité de l'argumentation, and The Uses of Argument), I had the opportunity to criticise this view and to show that it ultimately reduces argumentation theory to a theory of argument, void of true philosophical presuppositions (Ribeiro 2009). Regardless of the fundamental interest in a "unifying perspective of reasoned discourse", like the one that philosophy itself could provide, what this amounts to is presenting, enlightening and clarifying the eminently pragmatic criteria underlying our assessment of arguments in general. In other words, if a argumentation theory does not lead to a theory of argument, one may quite legitimately suppose that it is not interesting enough. (We may include in such theories, for example, views like the ones of J. Habermas regarding argumentation, which I mentioned before.) Ralph Johnson, in his book Manifest Rationality: A Pragmatic Theory of Argument, summarised the ties between argumentation theory and the theory of argument as follows:

Argumentation theory refers to a theory involving logic, rhetoric, speech communication, composition, psychology, and so on. Thus, argumentation theory is the wide descriptor.-The theory of argument refers to that aspect of argumentation theory devoted to the study of the product of the practice: the argument itself. (Johnson 2000: 31)

If my analysis is correct, I believe that we may draw the following conclusion as to the parallel between analytic philosophy and argumentation theories: philosophically speaking, while for the former meaning does not entail an argumentation theory, for the latter argumentation does not entail a theory of meaning. Although we may see, almost intuitively, that there is a more or less neutral plane on which both schools could establish a dialogue between each other, which would be extraordinarily advantageous to the development of the relevant concepts-exactly that plane on which the theory of meaning and argumentation theory reconcile-, it is this contrast that prevents practically all links or communication between the two, from a philosophical perspective. 


\section{Analytic philosophy and argumentation theory: meaning without argumentation vs. argumentation without meaning}

Since, for analytic philosophy, the theory of meaning does not involve, neither directly nor indirectly, an argumentation theory, some analytic philosophers use a tool for argumentation study, which is precisely the one provided by contemporary formal logic (specifically, propositional logic and predicate logic). I said "some analytic philosophers", because they are far from agreeing that, historically and philosophically speaking, formal logic may constitute such instrument. Actually, the development of analytic philosophy in the last half of the 20th century largely featured complete rejection of the idea that formal logic would be relevant to study how there can be meaning in ordinary language. On this, both English philosophy of ordinary language (namely, Austin and Ryle), and Wittgenstein's philosophy in Philosophishe Untersuchungen were essentially responsible for abandoning the formal logic paradigm as the fundamental framework of the theory of meaning. Further ahead, from this perspective, I will call your attention to some curious and surprising links between analytic philosophy and argumentation theory suggested, for example, by the research conducted within the scope of the latter theory by philosophers like Stethen Toulmin.

Let us begin by focusing on the idea of the analytic philosophers, mentioned before, that formal logic is to some extent a fundamental tool for argumentation study. Once again, the first thing I must say is that the principal value-added of applying this tool is not so much the study of argumentation alone - since analytic philosophers have not set the conceptual boundaries of the field of this study - but rather, essentially, the meaning in ordinary language in general. The presupposition, on the one hand, is that the language of formal logic and its inference schemes are the templates or moulds of ordinary language and of argumentation using ordinary language; or, rather, that these schemes are not only schemes of meaning but also of argumentation. So, there is meaning to the exact extent that we argue according to the inference schemes of formal logic. On the other hand, formal logic applied to argumentation via ordinary language is supposed to depend on that imperative that Russell and others introduced and supported in the first quarter of the 20th century: that such application is essential to achieve the necessary clarity and precision both in the use of the language and in the understanding of the concepts involved in that use. Consequently, the differences between formal logic applied to argumentation by some contemporary analytic philosophers and the same application that informal logic (Blair, Johnson, and others) criticised in 
the early nineteen-seventies, are not relevant from a technical perspective (see Johnson 1996: chap. 2, 32-51). The contrast lies essentially in the - more recent and somewhat surprising - idea that contemporary formal logic, on a par with informal logic itself, can also be used to create and develop critical thinking (see Ribeiro 2012b: 9-11).

It is an especially surprising idea, because, as I have suggested, it is far from consensual within the framework of the analytic movement, since the second half of the last century to this day, that the study of formal logic may play an essential part in understanding the issues we focus on in philosophy and, least of all, argumentation issues in particular. One must realise that this logic and the relevant inference schemes were not developed in principle, at the beginning of the 20th century, to explain argumentation, and least of all to find out how there can be meaning in ordinary language. Its core mission, particularly with Russell, was to produce the fundamental framework for research into the foundations of maths, subsequent to the crisis that hit its pillars from the end of the 19th century to (at least) the first quarter of the 20th century (see GrattanGuiness 2000: chap. 6ff.) This was, ultimately, the vocation of formal logic - not the study of meaning, and least of all of argumentation. That the explanation of the concept of meaning in ordinary language involves, to a certain extent, the same philosophical presuppositions as those involved in the study of these foundations, was rather a corollary than an axiom for the founders of contemporary formal logic. At least until Wittgenstein, in Tractatus Logico-Philosophicus, took a decisive step towards what later was called "linguistic turn" (Rorty 1967), thereby putting the theory of meaning at the heart of philosophical activity in general. This last transformation, however, as the progress in Wittgenstein's own thinking showed after that book, is itself closely linked, in the long term, with the rejection of the theory according to which formal logic is the fundamental framework for explaining the concept of meaning. (It was precisely such a theory that some of Russell's followers defended in the nineteen-thirties and forties, as was the case of Quine, up to a certain point in time.) English philosophy of ordinary language (Austin, Ryle, etc.), in the mid nineteen-fifties, turned this rejection into its mission, as happened later with Toulmin, albeit for different reasons, in The Uses of Argument. The same rejection is illustrated to some extent in the nineteen-sixties by the development of the philosophy of others, who were much more sensitive from the beginning to the idea of the importance of formal logic, like Quine at a certain point in his work (at least, until papers like those presented in Quine 1953). To place the theory of meaning as the first and only issue in the agenda of "analytic philosophy", as we now call it, like the authors I have just mentioned did, resulted in the underestimation, 
more or less permanent depending on the cases, of this idea and of its impact on philosophical thought in general.

Now, one must start by saying and underscoring that, when informal logic appeared in the nineteen-seventies, claiming that formal logic was entirely inappropriate for argumentation study, the main authors of analytic philosophy then had long concluded that formal logic could not provide the framework for the study of meaning. Informal logicians and analytic philosophers agreed to dismiss formal logic for several reasons: the former because it would not help argumentation studies, and the latter because it would not help the study of meaning. In the first case, as the development of informal logic to our days seems to indicate, the dismissal of formal logic was one way of abandoning not only the concept of meaning, but also the idea that argumentation would include philosophical presuppositions in the broad sense; i.e., the type of presuppositions that analytic philosophers justly tackled when they put the theory of meaning at the top of their philosophical agenda and which were, in the end, metaphysical in nature. ${ }^{5}$ (As I said in the introduction to this paper, argumentation was for the informal logicians, as it is today for argumentation theory experts, a neutral territory, irrelevant for philosophy in the last analysis, which is a scientific field on its own, i.e. with its own research problems and its own methodology. This fundamental consequence of discovering and exploring this new continent which is argumentation is truly surprising for us today, since most informal logicians and presentday argumentation theory experts were originally philosophers. $)^{6}$ In the second case (that of analytic philosophy), the dismissal of formal logic, which until the nineteen-sixties provided the only philosophical framework for argumentation study, ${ }^{7}$ strengthened the idea that the study of meaning would never involve argumentation, or that there would only be meaning

5 See Johnson (1996 : chap. 3, 76-86), where the author speaks of informal logic as the "naturalization" of logic in the broad sense, whose main task would be the "reconceptualization of argument". Compare this "naturalization of logic" with Quine's naturalization of epistemology in Quine (1969: chap. 4, 69-90), that is to say, with the rejection of the idea that epistemology would have metaphysical foundations.

6 The presupposition, as I showed in Ribeiro (2012b), would be that argumentation theory, in some sense, occupies the ancient role of philosophy in the Western tradition. Argumentation theory would replace philosophy for the best reasons. Eventually, this can be true and very pertinent, if we reinterpret philosophically argumentation theory, i.e. if the we ascribe to it philosophical foundations. This - I held in Ribeiro (2912b) - is entirely possible and can/must be done in the future. See again, from this perspective, Johnson (2000: chap. 2, 28ff.)

7 The most known example of this framework, at that time, is perhaps Copi \& Cohen (1953/1994). 
independently and regardless of argumentation. In both cases, the gap between meaning and argumentation led, more generally, to the divorce between philosophy and argumentation theory.

Further ahead I will attempt to show that Toulmin's important input, philosophically speaking, to argumentation theory implied that there is only meaning through argumentation, and vice-versa, that argumentation entails meaning, in other words it involves presuppositions philosophical in nature without which it cannot be understood. To what extent can we read the progress of analytic philosophy in terms of the theory of meaning-Wittgenstein and Quine particularly-in the light of that fundamental input?

I suggest we go back to the beginning of the story of the role of the theory of meaning and its link to argumentation in analytic philosophy. In the beginning, we do not find neither in Wittgenstein nor in Quine (in fact, not even in any other relevant author of this philosophy [K. Popper cannot be included here, since he never identified himself with it]) the simple idea of argument, least of all of a theory that would approach it as its study-object. (For those of us today, who know and are aware of the crucial importance of argumentation and its theories, this situation, like other situations which we have encountered until now regarding the link between philosophy and argumentation theory, is truly surprising and paradoxical.) The man in question in Wittgenstein's Philosophishe Untersuchungen and other works, as the agent of meaning, does not argue, that is, he does not seek reasons or grounds for his statements, or the statements of others, which in turn may be argued or contested rationally in such manner that, by doing so, he may arrive at a consensus or agreement with the people he is arguing with. ${ }^{8}$ In other words, Wittgenstein's "language games" are not argumentation games; its rules only truly make sense for Wittgenstein, because they are incorporated in actions or behaviour which are part, as he says, of the "grammar" of the locutions which take place in them, per context. Therefore, it is not possible to formally dissociate them from each of these contexts (like formal or informal logic would require in principle), and finally arrive at something like a "language games theory" (I know this is how J. Hintikka and others sought to interpret them, but these interpretations are reviews of Wittgenstein through philosophical presuppositions which we do not find in this author. [See Hintikka \& Hintikka 1986; and Saarinen (Ed.) (1997): 1-26]). Most of the reasons for

8 See in this sense the paragraphs $117 \mathrm{ff}$ in Wittgenstein (2001) about the status of philosophy. There is not a single mention of the terms "argument", "argumentation", "dialogue" or "dispute", in the Index of the famous book Wittgenstein's Place in the Twentieth-Century Analytic Philosophy (Hacker 1996). 
this, regard the deconstructive nature of Wittgenstein's philosophy: this implies, for example, showing the irrelevance of the traditional theories of meaning, like the ones of Russell. But the main reason probably is: the fundamental model of discourse according to Wittgenstein in Philosophishe Untersuchungen, is the monologue, not the dialogue or the dispute, and least of all the critical or argumentative dialogue, which Popper, for example, mentions in several of his papers published in his Conjectures and Refutations (Popper 1972) and, particularly, in The Myth of the Framework (Popper 1994), but which Toulmin, in his own way, started pointing out in The Uses of Argument (Toulmin 1958). ${ }^{9}$ And this happens even when in the language games of Wittgenstein two or more people intervene directly in the same context. It is still a monologue, or rather two (or more) monologues. The perverse presupposition of this monologue model, in philosophy (perverse at least a far as the role of argumentation is concerned), is that, as in literature (e.g. novels), the philosopher that applies it is the narrator and sees himself as a second (or third) party, when the truth is that he was not originally part of the context of his narrative. Well, he is part of it in his own way, so to speak, since he interprets and thinks about it; but this relation does not imply original belonging to the context in itself. In brief, the philosopher is a second or third party, fictional, and not an agent of meaning in a specific context or language game.

Similar reflections could be extensively developed about Quine and his well-known theses on the indeterminacy of translation and inscrutability of reference (Quine 1969: chap. 2). ${ }^{10}$ We also do not find in him the simple idea of argument, and least of all a theory or theories of argument. The indeterminacy of translation, although it can only be understood in context (as Quine warns from the start), ignores the essentially dialogical and argumentative nature of the entire context. From this perspective, the translation model in question in this indeterminacy (the radical translation) is an ideal model, a philosophical fiction. Resorting to Quine's famous example of radical translation, in Ontological Relativity \& Other Essays: to be able to communicate with the natives and to understand if the term "gavagai" applies or not to a rabbit or something else, not only should the visitor have some prior knowledge of the indigenous culture

9 See Ribeiro (2012c), where I explain the historical and philosophical connections between Wittgenstein and Toulmin.

${ }^{10}$ For contemporary analytical philosophy, Wittgenstein and Quine would be, in some sense, at the end of the history of analytic philosophy in the twentieth century. Apparently, we can find the same theses of Wittgenstein's philosophy in the philosophy of Quine. See, for instance, the papers collected by Arrington \& Glock (1996). 
and language and have started building the dictionary of the language (which means that the translation could never be entirely radical), but he should also be capable of interacting with them about the meaning of the term in that or subsequent contexts, while correcting throughout the process, his wrong interpretations, and finally concluding, as the story's narrator (the third party, fictionally representated by Quine himself), that it is a rabbit, for example. ${ }^{11}$ This is, however, not the essential point, but rather the following: the philosopher-narrator of the story, knows, from the beginning, that it is a rabbit and not something else. Yet, if the example is meant to be pertinent and not a fallacy, he should not know that information. In other words, although Quine is not originally part of the context of the radical translation of the term "gavagai", he enters it fictionally as the agent of the meaning of that term. Similar conclusions could be drawn regarding the inscrutability of reference: Apparently, it does not contain any argumentative dialogue that would make us attempt to clarify or precise it as far as possible, and arrive, finally, at a reasonable consensus about its objectivity. It is, notwithstanding, the same monologue model of discourse, of literary matrix, that Wittgenstein had adopted in his Philosophishe Untersuchungen.

Let me now tell you about the end of the story of the theory of meaning in analytic philosophy; the end, at least as far as the two main players are concerned (Wittgenstein and Quine). One of the most surprising and paradoxical results of the progress of analytic philosophy in this matter is that finally, as Quine said in the early nineteen-sixties, "the meaning is a myth"; or rather, the philosophical use of the concept of meaning is, generally speaking, a myth (Quine 1962). Such a result is paradoxical, because one can precisely say that analytic philosophy placed the theory of meaning at the top of the agenda of its research, while finally concluding that the concept of meaning itself is meaningless. Of course it is not a question of denying that ordinary language applies to circumstances, triggers replies, which is precisely why it has meaning. What Quine insurges against, namely, “c'est l'idée d'une identité ou d'une communauté de sens sous le signe, ou d'une théorie de la signification qui en ferait une sorte d'abstraction supra linguistique, dont les formes du langage seraient le pendant, ou l'expression. En somme, c'est à la signification en tant qu'idée que j'en ai." (Quine, 1962: 139) Wittgenstein had drawn a similar conclusion previously in Philosophishe Untersuchungen according to some

11 This is the point, against Quine, Kuhn and others, of the essay "The myth of the framework" in Popper (1994). Nevertheless, note that we cannot find in Popper's philosophy any precise theory about arguments or about the ways we argue. Regarding Popper and argumentation, see the essays collected in Suárez-Iñiguez (2007). 
reputable readers (see Gibson 1996; and Hacker 1996: 97-136). Meaning is a myth in the sense that it is essentially based on the use of language in context, and can be explained, not through any psychological factors (like our intentions) or epistemological ones (like the relation between an image or a concept in a person's mind and its external reference), but through factors of pragmatic and behaviourist nature, which concern our behaviour in these contexts. Quine develops this approach through his theories about the indeterminacy of translation and the inscrutability of reference; and Wittgenstein applies it particularly through his theory of "language games". As illustrated particularly by the example of the author of Ontological Relativity and Other Essays, the core reason for the dismissal of meaning is a more or less radical holism. Resorting to his language, briefly: to the extent that our conceptual schemes are generally the vehicle of meaning, and it is impossible to translate them fully (as is particularly the case of those that concern different cultures) or, ultimately, dissociating them from the context or the circumstances they apply to, all meaning and reference are essentially undetermined. This does not mean that it is somewhat impossible to build a theory of meaning: deconstructing the traditional theories on this matter and finally provokind the suicide of the "modern movement", as Wittgenstein in particular did (according to the reading of Toulmin \& Janik 1973); and more positively, elaborating such a theory within the strict boundaries of a physicalist and behaviourist psychology and epistemology, as with Quine (1969: chap. 4; and 1995).

Consequently, the issue of holism is at the root of this announced death of the theory of meaning in these authors' philosophies. And that this happened more or less at the time when contemporary argumentation theories began sprouting is quite significant, i.e., those theories which seem to forget that the meaning in question in argumentation, in order to be fully understood, is founded on philosophical and even metaphysical assumptions. I will come back to this next, with Toulmin, since, as his philosophy illustrates, one of the most relevant strengths of a possible modern reencounter between argumentation theory and the theory of meaning, and in parallel of a reencounter between philosophy and argumentation, would be precisely overcoming the challenges of holism and relativism, which are the core topics of western thought (if not its crux), from the second half of the $20^{\text {th }}$ century to our days. ${ }^{12}$

12 In developed this view, more recently, in Ribeiro (2012b). See below note 14 . 


\section{Toulmin's lessons: there is no meaning without argumentation, nor argumentation without meaning}

The primary thesis of The Uses of Argument, at least when perceived from the perspective of the historical-philosophical framework of the period in which the book was published, is that there is meaning fundamentally through argumentation. Toulmin's presupposition, on the one hand, is that asking for the meaning of any term or statement in ordinary language implies asking to what extent they are part of our justificatory activities in a given context of language use, and are therefore arguable. The aforementioned book shows how these justificatory activities characterise both ordinary language in general and the exercise of human reason at large. To have (or not to have) meaning, as far as ordinary language is concerned, now rather means being arguable or liable to argumentation. On the other hand, how these activities are performed is a question for a specialised field of studies, which should be conducted in the light of entirely different systematic and operative concepts, compared to the concepts of formal logic or of the theory of meaning developed by some schools of the analytic movement then (like the so-called "English ordinary language philosophy"). Practically up to his last book, Return to Reason (2001), Toulmin generally uses the traditional term "rhetoric" when referring to this field. ${ }^{13}$

Inversely, according to the Toulmin who goes from The Uses of Argument to The Return to Reason, through Knowing and Acting, our best understanding of that study field, which I have briefly described, must focus on the fundamental presupposition that meaning is far from being reduced to argumentation or, rather, to an argument theory, as the main schools of argumentation theory are apparently supporting now. Understanding the uses of argument, as he suggests already in his first book, is an endless task, since they vary with context (they are what he calls "field-dependent arguments"), and it is impossible, philosophically speaking, to identify all of the factors (or presuppositions) underlying the relevant meaning. (In Knowing and Acting, from this perspective, Toulmin concludes that it is impossible to define argumentation (Toulmin 1976: 273), and from his single model, in The Uses of Argument (Toulmin 1958: chap. 3), stemmed, as we know, three complementary approaches to the problematic of argumentation: the geometrical, the anthropological and the critical.)

13 At the same time that Toulmin introduced the ideas I have just mentioned, in The Uses of Argument, Chaïm Perelman supported similar ideas (Perelman \& Olbrechts-Tyteca 1958). For a comparison between Toulmin and Perelman, see Ribeiro 2009, and 2012a. 
In 1958, Toulmin introduced the revolutionary theses I have just mentioned, particularly against Quine, Carnap, Kneale and others, for whom formal logic, at least at the time, provided the essential framework of philosophical research. This logic is what he calls "idealised logic", primarily targeting at founding mathematics, and is entirely inappropriate for the study of argumentation in context (see Toulmin 1958: chap. 4, 146ff). (Note that the problem then for Toulmin was not so much that of applying formal logic to argumentation study, as is the case today for most argumentation theorists, but more that formal logic, when analysed from the perspective of its relation with ordinary language, did not even acknowledge the existence of argumentation as a specific field of research.) Furthermore, he introduced thoses theses against the English ordinary language philosophers (as J. Austin), since they made, inversely, meaning depend essentially on the multiple and diverse contexts it comes up in, without in the end enhancing their real theoretical or conceptual framework, and, particularly, without having any understanding of the idea that meaning will somehow include argumentation. He was definitely familiar with philosophers who, as G. Ryle, had insisted on the failure of formal logic and on the contrast between it and another type of logic - informal logic precisely -, more suitable for the study of meaning in context (Ryle 1956); and his book shows some appreciation of their work (see Toulmin 1958: 120-121). The fact, however, is that none of these philosophers had managed to understand the absolutely decisive role that the idea of argument plays in this type of study. In other words, English ordinary language philosophy also believed that the concept of meaning did not include argumentation at all (see, in this sense, Toulmin 1958: chap. II, and his remarks about Austin). The same must be said about the two Wittgenstein - the Wittgenstein of Tractatus and the one of Philosophishe Untersuchungen -, for which he never hid his deep admiration until his last book (see again Toulmin 1973, and Toulmin 2001: chap. 13; see also Ribeiro 2012c). Consequently, although he ignored, in the late nineteen-fifties, that the study of argumentation was already common in North-American universities within the framework of speech communication theory, Toulmin claimed quite revolutionarily, after Aristotle, having rediscovered an entirely new philosophical continent, which we currently call "argumentation theory" (see Toulmin 1958: 2-3).

The break from analytic philosophy, at the time, passed on to him as a break from formal logic as the fundamental framework of argumentation study. And later the analytic philosophers did not forgive his heresy, and ostracised his philosophy practically up to our days, by transforming a philosophical break into a real institutional divorce. But the fact is that Toulmin's rejection of formal logic was only partial: as The Uses 
of Argument illustrates, he believed that that logic can be transformed and extended through the same assumptions underlying his concept of argumentation, thereby appearing as a "working logic" or a "logic in action" (see Toulmin 1958: chap. IV, 146ff). In his book Knowing \& Acting, this idea of an extension of logic lead him to the thesis, which I mentioned previously, of three fundamental models that would complement each other in the study of argumentation: the logical, the anthropological and the critical. (Toulmin 1976: 249-261). When, some time after The Uses of Argument (as seen before), one of the lead players in the analytic movement (Quine), drawing the consequences of the impact of the holistic theses on philosophy, declared the end of the myth of meaning and, with it, the end of the myth of philosophy itself (see Quine 1953: chap. II, 20-46; and Quine 1962: chap. 2), apparently nobody saw that the path that Toulmin suggested, by connecting the problematic of meaning (a problematic such as that of Wittgenstein's philosophy) to that of argumentation, could have provided a privileged path for continuing to do Philosophy, and even, to some extent, "analytic philosophy". ${ }^{14}$ Therefore, in spite of the severe and exhaustive criticism of what he calls "idealised logic", that philosopher does not reject with his "argumentative turn", as early as 1958, the very same consequences that the philosophers of the "linguistic turn" (e.g., first G. Bergmann, then R. Rorty) claimed for the latter and its theory of meaning: to turn ordinary language into the real crux of philosophical research; the refusal of psychologism; the rehabilitation of metaphysics, to the extent in which such rehabilitation is, notwithstanding, compatible with the rejection of the traditional theory of knowledge (see the "Introduction" to Rorty 1967). It is from this clearly constructive and optimistic viewpoint that we must read the last chapter of The Uses of Argument (Toulmin 1958: 211-252, "The Origins of Epistemological Theory").

Anyhow, at the core of Toulmin's concept of argumentation is the idea that its study is essentially founded on philosophical assumptions, and therefore that it is far from being neutral or indifferent for philosophy, as today some argumentation theory experts sustain. The concepts of "strength" and "criteria" applied to the use of the modal terms, or

14 This is my point in Ribeiro (2012a) and Ribeiro (2012b). Rhetoric (or argumentation theory), for Toulmin (and to some extent for Perelman) would be the new way to do Philosophy after the end of our traditional concept of it. Holism, in philosophy, does not necessarily lead to relativism, as some theories of Wittgenstein and Quine suggest. It does not necessarily lead, in special, to the end of a systematic research regarding the foundations of knowledge, as the one that philosophy is supposed to provide. Philosophy would be always alive and in good health (but certainly not in the same terms of the past) as rhetoric or argumentation theory. 
the concepts of "field-dependent" or "field-independent" arguments, besides those linked to the theory of argument itself (see Toulmin 1958: chap. III), are exactly that, philosophical concepts, and not merely technical ones. (Of course, we can always cut the philosophical roots of his argumentation theory, reducing it to a theory of argument, and its concepts to strictly technical concepts, as apparently happens with some recent interpretations. See Hitchcock \& Verheij (2005). However, by doing so we sacrifice its true spirit.) Generally speaking, as for the philosophical nature of the assumptions of his argumentation theory, from The Uses of Argument and Knowing and Acting to Return to Reason, Toulmin was convinced that such theory should cover, not only the vast scope of reasoning as a whole (and how to achieve this was highly questionable for him, given the gap between knowledge and action, or, as he said, between the "rational" and the "reasonable"), but it should also apply to the broad problematic of holism in philosophy (as this problematic had been analysed by different authors, like Quine, Kuhn and Popper, for example) and to its devastating consequences for intercultural and intercivilizational dialogue. This is the fundamental message conveyed in his last books (Toulmin 1992, and 2001). From this last viewpoint, this philosopher's whole outlook on argumentation, particularly from Knowing and Acting onwards, seems to have been put to the service of the idea that, to the extent that argumentation is the ultimate expression of human reason, our best understanding of it is the way to overcome the devastating consequences of holism to which I alluded, particularly relativism and scepticism, when faced from a social, cultural and political viewpoint. Concluding, and as I outlined elsewhere (Ribeiro 2009: 42-48), argumentation theory for Toulmin was not so much a theory about our arguments (although it was also that), but it was rather a theory about human reason and its limits.

\section{Concluding remarks: the biggest challenge}

Toulmin's lessons show that, in order to be capable to do its job, any argument theory must be based upon a broad argumentation theory with strong philosophical (and even metaphysical) presuppositions, that is to say, upon a theory of meaning. Indeed, this was precisely Toulmin's road from The Uses of Argument to Knowing and Acting and his last book, Return to Reason. Against the conclusions of analytic philosophy in the $20^{\text {th }}$ century (particularly, Wittgenstein and Quine), meaning is not a myth or a mere philosophical entity; ordinary language can always have meaning through argumentation and a Theory on it. But, in contrast to what seems 
to be defended by some contemporary argumentation schools, we cannot reduce meaning to the technical limits of an argument theory. The search for a theory of meaning lead us straight away to Philosophy and its eternal problems. Furthermore, Toulmin shows us that Rhetoric, or argumentation theory, is not simply a philosophical discipline among others; is at the core of Philosophy itself and, in fact, is the only appropriate way to do Philosophy after the collapse of the Cartesian myths regarding it. They also show that the fundamental task of Philosophy nowadays is just to accomplish an interdisciplinary role regarding the different specialised fields who contribute to argumentation theory. We have not discovered yet how to do that. The model of the Cartesian tree is no longer useful anymore. We have to invent new conceptual and systematic tools. In my view, this is the biggest challenge facing all of those who continue to believe, after what has been called "post-modernism", in philosophical foundations for human knowledge as a whole.

\section{REFERENCES}

ARRINGTON, R. L. \& GLOCK, H.-J. (Ed.) (1996). Wittgenstein and Quine. London/New York: Routledge/Taylor \& Francis Group.

COFFA, A. (1991). The Semantic Tradition from Kant to Carnap. Cambridge: Cambridge University Press.

COHEN, L. J. (1977). The Probable and the Provable. Oxford: Clarendon Press.

COHEN, L. J. (1986). The Dialogue of Reason. Oxford: Oxford University Press.

COHEN, L. J. (1989). An Introduction to the Philosophy of Induction and Probability. Oxford: Clarendon Press.

COPI, I. \& COHEN, C. (1953/1994). Introduction to Logic. New York: Macmillan Publishing Co.

EEMEREN, F. VAN, GROOTENDORST, R., HENKEMANS, F. et al. (Eds.) (1996). Fundamentals of Argumentation Theory. A Handbook of Historical Backgrounds and Contemporary Developments. Mahwah, NJ: Lawrence Erlbaum Associates, Publishers.

F申LLESDAL, D. (1997). Analytic philosophy: What is and why should one engage on It ? In: Glock, H.-J. (Ed.), The Rise of Analytic Philosophy (193-208).

GIBSON, R. (1996). Quine, Wittgenstein an holism. In: Arrington \& Glock (Ed.), Wittgenstein and Quine (80-96).

GLOCK, H.-J. (Ed.) (1997). The Rise of Analytic Philosophy. Oxford: Blackwell Publishers Inc.

GLOCK, H.-J. (2008). What is Analytic Philosophy? Cambridge: Cambridge University Press. 
GRATTAN-GUINESS, I. (2000). The Search for Mathematical Roots, 1870-1940: Logics, Set Theories and the Foundations of Mathematics. From Cantor Through Russell to Gödel. Princeton and Oxford: Princeton University Press.

HACKER, P. M. S. (1996). Wittgenstein's Place in Twentieth-Century Analytic Philosophy. Cambridge-Massachusetts: Blackwell Publishers.

HINTIKKA, M. B. \& HINTIKKA, J. (1986). Investigating Wittgenstein. Oxford: Basil Blackwell.

HITCHCOCK, D. \& VERHEIJ (Eds.) (2005). Arguing on the Toulmin Model. New Essays in Argument Analysis and Evaluation. Dordrecht, The Netherlands: Springer.

KATZ, J. (1990). The Metaphysics of Meaning. Cambridge-Massachusetts/ London: The MIT Press.

JOHNSON, R. (1996). The Rise of Informal Logic: Essays on Argumentation, Critical Thinking, Reasoning and Politics. Newport News, Virginia: Vale Press.

JOHNSON, R. (2000). Manifest Rationality: A Pragmatic Theory of Argument. Mahwah, NJ/London: Lawrence Erlbaum Associates Publishers.

MARTINICH, A. P. \& SOSA, D. (Eds.) (2001). A Companion to Analytic Philosophy. Oxford: Blackwell Publishers Ltd.

PERELMAN, CH. \& OLBRECHTS-TYTECA, L. (1958). La nouvelle rhétorique: Traité de l'argumentation. Paris: Presses Universitaires de France.

POPPER, K. (1972). Conjectures and Refutations. The Growth of Scientific Knowledge. London: Routledge and Kegan Paul.

POPPER, K. (1994). The Myth of the Framework. In Defense of Science and Rationality. London/New York: Routledge.

QUINE, W. V. O. (1953). From a Logical Point of View: Nine Logico-Philosophical Essays. Cambridge-Massachusetts: Harvard University Presss.

QUINE, W. V. O. (1962). Le mythe de la signification. In: J. Wahl et al. (Coord.), La philosophie analytique (139-169). Paris: Les Éditions de Minuit.

QUINE, W. (1969). Ontological Relativity and Other Essays. New York: Columbia University Press.

QUINE, W. (1995). From Stimulus to Science. London: Cambridge-Massachusetts/ London: Harvard University Press.

RIBEIRO, H. J. (2005). 'Critical thinking', retórica e filosofia. In : Actas do $1^{\circ}$ Congresso Virtual do Departamento de Literaturas Românicas: Retórica. CD-ROM. Lisboa: CLEPUL.

RIBEIRO, H. J. (2009). Perelman and Toulmin as philosophers: On the inalienable connection between philosophy, rhetoric and argumentation. In: Henrique J. Ribeiro (Ed.), Rhetoric and Argumentation in the Beginning of the XXIst Century (33-54). Coimbra: Coimbra University Press.

RIBEIRO, H. J. (2012a). Rhétorique et philosophie: Perelman et la philosophie analytique. In: B. Frydman \& M. Meyer (Eds.), Chaïm Perelman (1912- 
-2012): De la nouvelle rhétorique à la logique juridique (161-185). Paris: PUF.

RIBEIRO, H. J. (Ed.) (2012b). Inside Arguments: Logic and the Study of Argumentation. Newcastle upon Tyne (UK): Cambridge Scholars Publishing.

RIBEIRO, H. J. (2012c, forthcoming). What about argumentation in Wittgenstein's philosophy? On Stephen Toumin's connections. In: M. Weiss \& H. Greif (Eds.), Proceedings of the 35th International Wittgenstein Symposium, Kirchberg am Wechsel.

RORTY, R. (Ed.) (1967), The Linguistic Turn. Recent Essays in Philosophical Method. Chicago and London: The University of Chicago Press.

RYLE, G. (1956). Dilemmas. The Tarner Lectures: 1953. Cambridge: At the University Press.

SAARINEN, E. (Ed.) (1979). Game-Theoretical Semantics. Dordrecht: Springer.

SUÁREZ-IÑIGUEZ, E. (Ed.) (2007). The Power of Argumentation. Amsterdam and New York: Rodopi.

TOULMIN, S. (1958/1991). The Uses of Argument. Cambridge: Cambridge University Press.

TOULMIN, S. \& JANIK, A. (1973). Wittgenstein Vienna. New York: Simon and Schuster.

TOULMIN, S. (1976). Knowing and Acting. An Invitation to Philosophy. New York and London: MacMillan Publishing Co., Inc., and Collier Macmillan Publishers.

TOULMIN, S. (1992). Cosmopolis: The Hidden Agenda of Modernity. Chicago: The University of Chicago Press.

TOULMIN, S. (2001). Return to Reason. Cambridge-Massachusetts, and London: Harvard University Press.

WitTGENSTEIN, L. (2001). Philosophical Investigations. Transl. by G. E. Ascombe. Oxford: Blackwell Publishers. 